Ілля СГОРОВ

\title{
«ПОВАГА ДО КАДРУ»У ДОКУМЕНТАЛЬНОМУ КІНО: ОПЕРАТОРИ В. КУКОРЕНЧУК ТА А. ХИМИЧ У СПІВПРАЦІ 3 РЕЖИСЕРОМ С. БУКОВСЬКИМ
}

Стаття шляхом аналізу ключових творів фільмографії, статей, особистих висловлювань режисера у інтерв'ю та на творчих зустрічах, вивчає візуальні образи, методи щодо операторської роботи та ставлення до кінематографії як такої визнаного у всьому світі украӥнського документаліста Сергія Буковського.

Ключові слова: Сергій Буковський, Володимир Кукоренчук, Анатолій Химич, Вілен Калюта, українське документальне кіно, українська операторська школа, кіно доби перебудови, кіно незалежної Украӥни, плівка, кадр, документ, пам'ять.

Статья путем анализа ключевых произведений фильмографии, статей, личных высказываний режиссера в интервью и на творческих встречах, изучает визуальные образы, методы в отночении операторской работы и отношение к кинематографии как таковой признанного во всем мире украинского документалиста Сергея Буковского.

Ключевые слова: Сергей Буковский, Владимир Кукоренчук, Анатолий Химич, Вилен Калюта, украинское документальное кино, украинская операторская школа, кино эпохи перестройки, кино независимой Украины, пленка, кадр, документ, память.

This text analyzes the best films, articles, personal statements and interviews of the world-recognized Ukrainian documentary filmmaker Serhii Bukovskyi. The main subjects of the research is the visual style, cinematographer's work and personal director's relationship with cinema itself.

Key words: Serhii Bukovskyi, Vladimir Kukorenchuk, Anatolii Chemich, Vilen Kalyuta, Ukrainian documentary, Ukrainian cinematography school, cinema of the "perestroika» period, cinema of the independent Ukraine, film, frame, document, memory.

«Робота кінооператора зробити зі слів дещзо більще, ніж вони є самі по собі. Змусити слово резонувати, розчинитись подихом у просторі, розквітнути у колір.

Але також ие відмова від слів. Відсунути слова вбік - хай зображення само говорить за себе. Це той важливий баланс, який треба знайти»

Крістофер Дойл, кінооператор

«Зніміть заздрість. Зніміть любов. Зніміть тишу. Зніміть те, щуо невидиме, але відчутне»

$[2,15: 40]$.

Володимир Кукоренчук, кінооператор

«Якщо коротко, можливо, занадто безпосередньо: наше кіно, культура в цілому, припинила займатися смислами. Стрімко змінюються технології. Сьогодні будь-яка людина, взявши мобільний телефон до рук, може зняти документальний фільм. Але чи буде він предметом мистецтва? Я не певен. Ніхто особливо не замислюється про культуру кадру, про його виражальну функцію. Нечасто таке буває, що документальне кіно взагалі щось досліджує», — каже Сергій Буковський, визнаний у всьому світі український документаліст [3].

Його роботи розглянуті культурологом Лілією Зінченко [4], кінознавцем Іриною Зубавіною $[5,22]$, кандидатом філософських наук М. Міщенком [6]. 3 ним записано безліч інтерв'ю та майстер-класів. Будучи учнем видатного режисераоператора Олександра Коваля, він передає естафету української кінотрадиції, засновуючи власну 
кіношколу та долучаючи до викладання найкращих представників галузі. Проявивши себе як камертон соціальних зрушень, майстер історичного аналізу, Сергій Буковський не перестає бути, передусім, послідовним захисником кіно як мистецтва, проповідником певної естетики. Візуальні образи та методи режисера, його позиція щодо культури кадру, операторської роботи та кінематографії як феномену є предметом дослідження цієї статті.

Режисер-оператор Української студії хронікально-документальних фільмів Володимир Шевченко був чи не єдиним документалістом, який виборов право на «допуск усюди» під час зйомок ліквідації аварії на 4-му енергоблоці, що сталася 26-го квітня 1986-го року [12]. Фільм Шевченка «Чорнобиль - хроніка важких тижнів» починається телетрансляцією - заявою Горбачова про ліквідацію аварії, наслідки якої нібито під контролем. Інтертитр у записі датує заяву 14-м травня. Це був перший офіційний виступ з цього приводу.

Замовчування стало чи не більшою катастрофою, ніж сам вибух. Про ураження повідомила Швеція, тоді як радянська влада злочинно затримувала евакуацію. Першого травня вітер з ЧАЕС віяв у бік Києва, демонстрація до Міжнародного дня солідарності трудящих відбулася за планом. А 3-го травня з Києва транслювали велогонку.

Дозвіл на оприлюднення будь-яких кіноматеріалів 3 місця трагедії мав пройти крізь Міжвідомчу комісію, ЦК, Політбюро, Головліт, Держкіно. Попри викривлення та рафінування цензурою, картину Володимира Шевченка згодом придбали 132 країни світу, вона отримала дев'ять нагород на міжнародних фестивалях [12].

Чорнобиль став одним з передвісників, чи то причин, розпаду СРСР. Витік радіації для Радянського союзу був не такий страшний, як витік інформації.

До першого травня 1987-го Володимир Шевченко вже не дожив. Помер від променевої хвороби. Проте перед самим святом, десь не так далеко від зони ураження, у селі Морозівка Київської області, відлунням до телетрансляції Горбачова від робітничого хору прозвучить суворе: «Вперед, друзья, вперед, вперед, вперед!» — це у село до великого всесоюзного свята приїхала досвідчений музичний педагог. Вона прибула потягом, а робітники, наче у перших сюжетах стрічок братів Люм'єр, виходили до неї з фабрики. Вона принесла у голосі та жестикуляції мужній натиск наступаючих на людські душі планів п’ятирічки. «Вперед, друзья, вперед, вперед, вперед!» — під акордеон.
Прибуття потяга у Морозівку стане вступним кадром першого визнаного у кіносередовищі фільму Сергія Буковського. На той час молодий режисер вже кілька років працював у штаті Укркінохроніки, вчився професії, асистуючи старшим колегам. Завдання зняти стрічку на дуже актуальну тему — про необхідність своєчасної зупинки виробничого процесу для проведення санітарних робіт на птахофабриці (з місткою проектною назвою «Санітарний розрив») [9] - було провалено. Сценарій не відбувся на екрані, картину не пускали у прокат сім місяців.

«Спочатку з'являвся цивільний цензор. Потім військовий. Вони сиділи у кінозалі й у гордій самотині, передивлялися всю студійну продукцію. Особливо суворими й непохитними були військові цензори. Вони могли “повернути фільм" на переробку. Їх зоною відповідальності було, щоб у кадрі не з'являлися військові об'єкти. Заводи, військові частини, мости. Не дай Боже! Бо ж ворог із блоку НАТО не дрімав! Смішно згадувати. Американський супутник уже зробив фото Красної площі, і Ніксон подарував його Брежнєву. Але цензори приїздили все одно.

$<\ldots>$ Досить часто фільми відправляли до ідеологічного відділу ЦК КП України. Там сиділи досвідчені товариші, у тому числі з КДБ, відповідальні за правильний курс партії. А раптом якийсь режисер (бо були й такі), особливо не член компартії, у прихованій, завуальованій формі, зводитиме наклеп на радянську владу! Ось такий довгий шлях до широкого глядача» [3].

Наче дисиденти поетичного кіно «відлиги», Буковський провіщає та надихає свободу думки під час перебудови. Дебютний фільм - «Завтра свято» (1987) - стає яскравим прикладом авторського, рефлекторного, неформального кіно. Хронікальне стає художнім, а рутинне студійне завдання перетворюється у незалежний вислів.

Ще замолоду С. Буковський знаходить питання, яке хвилюватиме його впродовж усієї кар'єри, до якого він повертатиметься більшою чи меншою мірою в кожній роботі. Він торкатиметься різних тем, але наскрізним образом для нього стане людина навпроти екрана. Режисер виявиться Дзигою Вертовим навпаки - людиною не 3, а проти апарата, проти державного апарату пропаганди чи телевізійного апарату невігластва. Екран, плівка, документ часто ставатимуть дійовими особами його фільмів. А культура кіно та кадру будуть найвищими цінностями, що з собою несуть право людини на правду, пам'ять, свободу слова. 
Перші роботи на Укркінохроніці зводять Буковського з на той час уже досвідченим студійним оператором Володимиром Кукоренчуком. Разом вони знімуть «Завтра свято» (1987), «Сон» (1988), «Дах» (1990), «Пейзаж. Портрет. Натюрморт» (1993), «Назви своє ім’я» (2006), «Живі» (2008) та ін. [10]. Через тридцять років після початку співпраці Буковський візьме у Кукоренчука інтерв’ю, в якому поставить фундаментальне запитання: хто у документальному кіно головний? Кукоренчук відповість, що в кіно на підготовчому періоді, під час обговорення концепції, - безперечно, головний режисер. Але на майданчику вже нема часу для дискусій та прикладних завдань. Оператор іде у вільне плавання.

«Ігрове кіно - це симфонічний оркестр. Там все по нотах розписано, головне, щоб була злагодженість. А документальне - ие джаз. Оператор у документальному кіно починає імпровізувати на дану тему»,- каже Кукоренчук. [2, 3:20]. I Буковський погоджується, що нетактовний режисер може навіть завадити операторові - людині, яка увійшла у певну подію та виражає реальність через об'єктив, «наводить фокус». Оператор є очима режисера.

У методі роботи Буковського з оператором діють інтуїтивна довіра та плідний симбіоз, а не маріонетковий контроль. Оператор для режисера дуже шанована особа, співавтор. «Ти не можеш весь час не довіряти оператору і втручатись в його [робочий] процес. Треба ставити точні завдання. $€$ монітор, є період, коли ти передивляєшся матеріал з оператором - ти можеш сказати, що добре, що ні. Візуальне рішення фільму треба продумувати. Я до кадру, до зображення, ставлюсь з великою повагою». [11, 48:21].

Режисер, безперечно, не залишає операторові довільний вибір візуальної концепції - вона завжди є похідною від головної мети та драматургійної структури фільму, виробляється шляхом спільного творчого пошуку, шліфується аналізом вже відзнятого матеріалу.

Своєю позицією режисер захищає не лише колег чи друзів по цеху, а й саме мистецтво кіно як таке. Інструмент кіно стає доступнішим, відеоконтент демократизується через соціальні медіа, розмиваються межі між дилетантним та популярним, беззмістовним та успішним. У інформаційному шумі найважливішим стає короткочасне привернення уваги, сенсація. Зникає попит на естетичне сприйняття дійсності. За словами відомого філософа постмодерну Жана Бодрійяра, «ми перебуваємо у світі, в якому де- далі більше інформації і дедалі менше смислу». $[13,117]$.

Буковський активно протиставляє документальне кіно вітчизняному телевізійному простору, відстоює людську особистість перед квазіжиттям та квазіпочуттями [7], які продукуються політизованими та комерціалізованими медіа. «Людина тупіє», — каже героїня фільму «Завтра свято» про побут навпроти телевізора. Телебачення разом 3 руйнуванням сенсів також руйнує і мистецьку естетику кадру.

«Кадр все ж таки має свою силу. Я ставлюсь до нього $з$ повагою. Сьогодні, коли настала епоха мобільних телефонів, на це не звертають увагу. Сам факт, що ти вхопив шматок реальності за допомогою сьогоднішніх маленьких камер, які роблять чудеса, говорить лише: “А ти тут до чого?”» $[11,49]$.

Кукоренчук називає Буковського чи не єдиним режисером, який каже про свої фільми не «я зняв», а «ми зняли». Як викладач фотографії та фотохудожник, В. Кукоренчук дуже чітко розуміє, наскільки важливі для оператора свобода та прихильність режисера. Іноді внутрішньокадровим монтажем можна розкрити всю авторську позицію стрічки, портретом - людську емпатію, рухом камери - історію. Рефлексії оператора передаються у матеріалі та разом 3 копітким, уважним монтажем утворюють справжню просторово-часову поезію. Отримавши від режисера ключові думки, сильні інтенції, оператор не просто виконує технічну чи хронікерську функцію,- - він рухається до свого надзавдання: зняти те, що $є$ невидимим. Улюблені моменти роботи Володимира Кукоренчука - здивування режисера, коли йому на монтажний стіл оператор приносить несподівані знахідки. Завдяки операторові у фільмі можуть виникнути нові герої, цілі епізоди, врешті-решт - підтексти.

Так само, як крізь десятиліття у стрічці «Завтра свято» лунають українські пісні та надії, так само, як тримає медитативну напругу нелінійний вертикальний монтаж, так само, як з кожним повторним переглядом у глядача виникають нові шари сенсів, які з роками лише набирають свою актуальність, - так само і вибудувані композиції, деталі, спостереження, акценти, вмотивовані наїзди трансфокатором, багатоплановість та смислові переводи фокуса з кожним переглядом набувають нових значень, створюючи врешті образ епохи.

Довгофокусна оптика, що зробила з прибуваючої електрички із «Завтра свято» масивного розмитого монстра; зауважливі, синхронні, 
3 людською пластикою та текстом панорами по героях, їхніх рухах, навколишніх об’єктах; трансфокація на мовчазну жінку, яка чистить картоплю під час загального галасу. Прохід камери 3 курника та курки, котра помилково опинилась на клітці понад іншими, непомітно, крізь темне тло, монтується у рух коридором гуртожитка - похмурого, тісного, бідного та насиченого дією, як у Олексія Германа. «Угрюмый лес стоит стеной кругом!» Безупинна підготовка до вічно завтрашнього й ніколи не сьогоднішнього свята прийдешнього комунізму та кращого життя та образ дитини, яка вибігає на сцену, тримаючи ручки позаду крильцями, а потім опиняється закинутою у вантажівку, далі на конвеєрі, де 3 неї обскубуть пір'я й повісять за шию на гак — всіх поспіль, мільйонами.

Під кам'яним наглядом Леніна парад вестимуть білий голуб - як символ миру та смажена курка, що крутиться на грилі. Точне, інтелектуальне бачення оператора дає змогу режисерові створити поетичне свідчення навколишнього абсурду, показати нащадкам документ позаілюзорної дійсності.

Короткометражний фільм «Дах» 1990-го року гіперболізує та обарвлює три крапки, залишені 3 «Завтра свято». Сталінські табори, зруйновані долі, старість, каліцтво, божевілля. Чорно-білі умовності та сюжетна стриманість зникають, конфлікт з реальністю загострюється.

Наскрізною лінією картини є «свята брехня» жінки, яка підробляє (у тому числі приурочуючи до свят) листи, щоб порадувати назавжди забутих адресатів - підопічних інтернату для душевнохворих.

Окреслена з важкої темряви задньо-бічним караваджієвським світлом, жінка займається буденною справою у своєму звичному середовищі - на тлі радянської барви гардин вона компонує стінну газету, буквально випускаючи з рук чи то літери, чи то сенси. Інтерв'ю з нею має характерне та витончене візуальне рішення - бордове тло за обличчям, високо, поза кадром, розташоване вікно, 3 якого вузьким променем б'є пряме сонце; час доби, положення героя відносно джерела світла, розташування режисера відносно камери для правильної лінії погляду, та власне обрання місця для розмови, виокремлення 3 нього мінімалістичного кадру - всі ці елементи фактично перенесли героїню з темної підсобки у намолену сповідальню католицького храму. Вона опікує заблукалі мирські душі та водночас сама потребує сповіді. Та культура, яку вона несе, прописана піснями про
Леніна у повістках політбюро. Хто продовжить ii справу? Хто оцінить нею зроблене?

Димар, на якому жили лелеки, закоптився чорним димом. На даху врешті відремонтували червону зірку — подібну до таких, що позначають могили у бур'яні, - але з лампочками.

Короткометражний фільм «Дислокащія» та повнометражний «Знак тире» 1992 року, а через більш ніж два десятиліття - «Головна роль» (2016), Сергій Буковський зняв разом з оператором Анатолієм Химичем.

Есеїстичний стиль «Дислокації» формує притчу на протиставленні двох реальностей грубої камуфляжної та незайманої дитячої. Панорама по абстрагованих деталях, від військових чобіт до касетного програвача під пісню В. Цоя, розкриття та акцентування трансфокатором, лаконізм монтажного рішення. «На десять хвилин старше» Герца Франка віддзеркалюється у Буковського словами Ф. М. Достоєвського 3 «Братів Карамазових»: «Счастье всего мира не стоит одной слезы на щеке невинного ребёнка».

Майже німа та беземоційна «Дислокація» розширюється та переосмислюється у повнометражній картині «Знак тире» - особистісним, нелінійним i, можливо, найтоншим твором документаліста. У цьому фільмі з'являється закадровий голос - ліричний, медитативний образ режисера. У кадр потрапляє і сам автор. Кінематографічна сім'я, радянський спадок та неспокійна сучасність створюють у Буковського особливий запит на дослідження сили плівки та екрана як таких. Кіно, пам'ять та спадкоємність стають для нього спорідненими саме у «Знаку тире».

«Це був якраз той випадок, коли був написаний доволі детальний сценарій. Наш редактор Валя Маркова нам сказала: “Що ви задумали? Вам доведеться робити фільм $з$ повітря”. I вийшло таке кіно про Віру Холодну, про той час та про наш час. Ніби поєднали непоєднуване. 3' явилась у фільмі Валя Ліберман, монтажер, з якою я зробив майже усі свої фільми на "Хроніці", потім Карабах, доньки Холодної в Сан-Франциско. Як ие все поєдналось в один фільм, я вже не пам'ятаю...» [17].

Як і у «Даху», однією з наскрізних героїнь фільму є жінка, яка вручну буквально маніпулює сенсами, інформацією, документом, - але замість паперових літер іiі фонетика складається 3 желатинових кадриків. Будучи інженером монтажу на кіностудії, вона стає провідницею у світ надконтрастних військових переживань та німих романтичних сцен. Її монтажний стіл, разом з плівкою 
та екраном, стає ключем до асоціативних рядів Буковського, одним із постійних елементів його символіки.

«Я не вважаю, що це мій найбільш вдалий фільм. Просто він найвільніший і найулюбленіший. Не думали, та й не знали ми тоді, що таке рейтинги, частки, цільові аудиторії. Знімали, покладаючись на почуття, інтуїцію, не озираючись. Композитор Вадік Храпачов спав у звукоцеху, аби не марнувати часу, не ходити додому... Перезапис — свята річ... Після другої частини накривався стіл у монтажній. Оператор Химич увесь карабахський матеріал знімав на нечутливій звуковій плівці 3Т (вона дає страшенний контраст, майже графіку). І він сидів цілодобово в ЦОПі, трусився над негативом, найменша помилка під час проявки — i все, кінець. Узагалі так ми працювали тоді. І думали, що так буде завжди...» [14].

Знятий «Знак тире» не менш вільно та рефлексійно, ніж задуманий. Прохід сонячно-тіньовим подвір'ям, що почитає фільм, імітує ходу, кут зору та душевні ритми ліричного героя, мову якого ми чуємо. (Подібний прохід, але коридором гуртожитку, ми бачили в «Завтра свято» - там він теж утворював третій сенс, вертикально монтуючись із піснею.) Закільцюється «Знак тире» проходом по ЦОПу — крізь «банки» плівки, нагромаджені під стінами коридора Укркінохроніки проти світла. Рух камери від вступу до фіналу тримає у русі (чи бере з собою у подорож) підсвідомість глядача - від народження, кольорових спогадів дитинства, до білого світла, що освітлює стоси пам'яті. Знак тире - це те, що стоятиме між датою народження та смерті, а плівка — те, що свідчитиме: тире було не лише розділовим знаком.

Особлива графіка звукової плівки, яка відіграла свою неймовірну сюрреалістичну роль у «Криниці для спраглих» (1965) Юрія Іллєнка, та, попри заборону цієї картини до 1987-го року, утворила один $з$ центральних візуальних образів українського поетичного кіно, допомагає Анатолієві Химичу продовжити писати поетичні білі чи чорно-білі вірші у кіно документальному.

Перший кадр карабахської лінії - солдат у затриманому на монтажі часі покадрово закидає на високу стіну трос з гаком. Трос асоціюється з тим, по якому бігає пес на задвірках кіностудії. Епізод військового похорону закінчується силуетом солдата, який по стіні, наче птах у небі, окремими уривчастими кадрами літає на тій мотузці з боку в бік. Трос - як натягнута струна людських доль, що бринить крізь час, — від німого кіно до онімі- лого сьогодення,- також є певним відсиланням до розділового знаку з назви.

Режисер з оператором не зупиняються лише на самих експресивних властивостях надконтрастної плівки - вони йдуть далі, руйнуючи «четверту стіну» між зображенням та глядачем, і у монтажі стикають власний матеріал з деталлю монтажного стола, на якому він програється, та з екраном, на який він проектується. Умовність кіно руйнується також у озвученні звукорежисером дати, місця та обставин запису інтершуму, що є технічною рутиною, виконуваною задля ідентифікації аудіозапису, але використаною в монтажі ніби голос диктора: «... задворки киностудии, вдоль проволоки бегала собака». Це абсолютно непомітні, на рівні двадцять п'ятого кадру, моменти, такі ж, як використання інтертитрів 3 німого кіно у власному монтажному ряду чи як неодноразова вклейка калібровочної кольорової міри 3 жіночим обличчям, спонукають до багатошарового, неочевидного сприйняття. Кіно як документ, документ як ілюзія. Плівка як самостійний персонаж.

Напрямок, у якому рухається оператор, буває ірраціональним - персонажем стає і камера. Подібно до згаданої панорами по чоботях у «Дислокації», Химич знімає майже трихвилинну панораму від купола собору, крізь балконну решітку, полущену фарбу на ній, прив'язані мотузки для білизни та паросток з листям - до обличчя на монументі Вірі Холодній. Панорама закінчується відкриттям діафрагми та зведенням у разфокус; режисер бере кадр у монтаж, як самодостатній вислів.

Сміливість «Знаку тире» показова також у епізоді з одеським парком атракціонів. За кадром ідеться про знищення кладовища через негативний вплив хрестів на молодь, у кадрі - динамічні перекидання по експонатах кімнати жахів. Цей епізод, можливо, найемоційніший у фільмі, бо підтексти, які він містить, вловлюються не одразу й не на логічному рівні. Дитячі страхітливі опудала у темряві атракціону на якийсь момент стають душами тих незаспокоєних, чиї могили було розграбовано колись у цьому місті. Або, навпаки, кімната жахів є пеклом для тих партійців, хто освятив руйнування. Передує епізодові загальний план плацу, де щойно пролунав траурний марш, солдати отримали команду «Вільно!» та за секунду розійшлися, ведучи буденні розмови. Смерть це не лише кров чи насильство, але і втрата пам'яті.

У пресі Сергій Буковський розкриває один зі своїх способів структурування знятого мате- 
ріалу - спочатку він монтує фінал, а потім вибудовує сюжет до кінцевої крапки. Символічний кадр на звалищі кіностудії був одним з таких відправних фіналів. Двоє чоловіків викидають з візка жіночий манекен у купальнику. Він зроблений 3 легкого матеріалу, має обламані руки і голову, наче Венера Мілоська, та гіпертрофовані форми, як у скіфських баб. Плине дим, на задньому плані стоїть макет танка. Згадується бабуся, що померла у день, коли народився Сергій, і дивиться на нас зі старих фотографій; Віра Холодна, що звертається до кінематографа: «Мой великий немой!» і згасає, разом із згасанням заводної музичної шкатулки; жінка за монтажним столом, яка дозволяє собі плакати лише наодинці; жінка у камуфляжі, яка керує чоловіками й не задумувалася про жіночий ідеал («Молчи, грусть, молчи» - у інтертитрі); дві доньки Віри Холодної, які блукають від Чорного моря до Тихого океану, розчиняючись у неймовірних пейзажах. «Знак тире», як і згодом «Головна роль» (2016) стає елегією жіночої долі.

«Знак тире» також стає першою картиною режисера, побудованою на хроніці. Кінематографічний антураж, натюрморти 3 фотографіями, образ плівки як носія пам'яті, руйнування умовностей екрана підводять глядача до вже втрачених світів минулого, покритих повздовжніми подряпинами, котрі поступово зникають. Як бобина плівки, що добігла кінця та шелестить, рухаючись за енерцією вхолосту, наша пам'ять потребує не лише відтворення, а й монтажу з сучасністю, 3 проекцією у майбутнє. Історія не існує лише на сухому програші, їй потрібна рефлексія та співпереживання — як людині.

Продовжуючи дослідження кінематографії, у 2001-му році Сергій Буковський випускає фільм «Вілен Калюта. Реальне світло». Як і Віра Холодна у «Знаку тире», український оператор Вілен Калюта, чия кар'єра почалася з блискучої картини «Білий птах з чорною ознакою» (1970), стає героєм фільму посмертно - його образ збирається мозаїкою спогадів та кадрів. «Реальне світло» у назві вводить в оману — про світло йдеться небагато. Проте з вуст колег по майданчику чуємо про тонкий характер майстра, його творчу натуру. «Він не вмів працювати на чистій професії, без дуже активного емоційного увімкнення. Він мав у щось закохатись або щось зненавидіти, лише тоді він міг працювати»,- каже кінорежисер В'ячеслав Криштофович. Сергія Буковського насамперед цікавить жива людина по той бік камери, - людина, яку, на відміну від актора, ніколи не видно. Феномен творчої особистості стосується не лише живописця чи поета.

«Якщо я чогось добився тоді у своїх картинах, то це відбулося разом з Калютою»,- каже режисер Роман Балаян. Разом вони створили стрічки «Бірюк» (1977), «Польоти уві сні та наяву» (1982), «Поцілунок» (1983) та «Бережи мене, мій талісмане» (1986) - тонкі психологічні драми, що шукають ідеали свого часу. Балаян дякує операторові за те, що іноді той сам підштовхував його до зйомок, виводив зі зневіри у кіно. Їх творчий тандем утворює на своєму стику дещо більше, ніж суму роботи окремих професіоналів. Емоційне проникнення Вілена Калюти у матеріал, як і його гордий характер, не завжди відігравало продуктивну роль, проте було невід'ємною частиною народження твору мистецтва. Показово, що Сергій Буковський через творчу особистість Вілена Калюти вербалізує вустами його сучасників ті принципи, на яких у глибинному, неформальному сенсі будується його власна культура кадру.

У роботі над історичним телевізійним циклом «Війна - украӥнський рахунок» (2002), режисер використовує архівні матеріали тією мірою, де вони ледь не перевищують за кінцевим хронометражем відзнятий спеціально для фільму відеоряд. Проект «Назви своє ім'я» (2006) ставить перед режисером ще радикальніше з точки зору форми завдання - працювати з уже готовим архівом інтерв'ю, який зібрав фонд Шоа з метою хронікування свідчень жертв Голокосту.

Щоб уникнути типового для подібних тем пафосу, режисер вирішує вийти за рамки хронікованих бесід та розповісти власну історію - рефлексію щодо побаченого, почутого, пережитого під час роботи на фільмом. Буковський перевертає публіцистичний шаблон та дистанціюється від матеріалу, показуючи його у рамці екрана, у вигляді наближених пікселів, інформаційного потоку, що відтворюється тут і зараз. Повторюючи сюжетний прийом «Знаку тире», режисер обирає своїми героями жінок за монтажним столом, які не лише оперують плівкою, а й співпереживають ій. Розшифровуючи синхрони, вони набирають текст у темній кімнаті, а згодом сповідаються самі, як героїня «Даху».

«А втік тільки я сам, щоб донести тобі»,цитує Буковський книгу Йова. Прірва забуття між поколіннями скорочується. Молоді студентки перед екраном стають історичними медіаторами, дзеркалом сучасності, спрямованим у минуле. Інструмент їх пам'яті — кіно. 
«Назви своє ім'я» режисер знімає 3 Володимиром Кукоренчуком та Романом Сленським. Сюжет з розшифруванням синхронів, котрий показує містерію дотику до живого минулого, розкадрований до найменших деталей - до окремих слів на моніторі. Певний фаталізм та емпатію несе і сама магнітна плівка, вона не витримує абсурду людської сутності та відмовляється працювати. Екранний світ перетинається і проникає у реальний, щоб наділити сучасність (знак тире) забутими сенсами. Вершина цього проникнення - сцена у потязі, у якій виконується наїзд та панорамування усередині архівного синхрону, що наділяє його художнім суб'єктивним поглядом, а потім - панорамування поза синхрон, поза рамку зображення, що непомітно виводить пряму мову у пейзаж. I хоча далі цей прийом розкривається і глядачеві дають побачити ноутбук, що стоїть на столі купе, ефект спорідненості та близькості двох віддалених світів не зникає.

Зображально виділеною є також сюжетна лінія літньої пари, що живе у колишній синагозі вона подана з таким же контрастним ефектом звукової плівки та пропущених кадрів, як карабахський матеріал «Знаку тире». До німого чорно-білого зображення доданий тон сепії. Час у цього подружжя невпинно сповільнюється, вони стають схожими на фотографії у старому альбомі.

Візуальними знахідками та закадровим монологом Буковський вводить сучасну натуру у медитативний контекст минулого. Холодний зимовий пейзаж, хуртовина, чорно-білі подвір'я, сонливий зал очікування на вокзалі, покинуті будинки, крижані брили, низьке сліпе сонце, сірі дерева - та питання до бога від очевидців нелюдяності. Асоціативність та емоційна прив'язка діють сильніше, ніж гучні слова та знеособлена статистика. Документальне кіно значно ширше за вербальні тези, у ньому озвучені,- воно демонструє невидиме.

«Живі» (2008) починаються білим екраном, що призначений для перегляду фотослайдів. Головним героєм Буковського знову стає кадр - на рівні з документом. Хроніка прискорено промотується у різних напрямах, на моніторі з'являються та зникають політичні ідоли, військові, цивільні. Екран зводить десятиліття у секунди, мільйони душ пресує у кілька партійних символів. Людина перед екраном заплющує очі - та всі історичні ілюзії відносить порив сніжного вітру. Щоб пізнати, треба зробити паузу, повернутися назад.

«Виявляється, свобода слова не завжди гарантує справедливість. Слово правди журналіста Гар- рета Джонса тоді не було почуте. Хоча він кричав на повний голос. І поплатився за це. Його почули лише в наші дні, 75 років потому. Європейський світ, ну, звісно, дипломатичні й політичні кола всі знали про Великий Голод. Писали, рапортували у звітах, що їх надсилали своїм урядам з України, зокрема, з її тогочасної столиці Харкова. Але ніхто не хотів сваритися зі Сталіним. Вважалося, що він усе ж кращий за Гітлера. Незабаром зрозуміли, що це одне й те саме. Сталін - Гітлер. Але було запізно. Почалася війна». [14]

Джазбенд московських хлібопекарів підкорює Європу. Пропаганда, якої торкається Сергій Буковський, є зворотним боком кінематографії, викривленням культури кадру. У постіндустріальному інформаційному світі вона є зброєю масового знищення.

Пейзаж у «Живих» отримує особливе місце топографічного свідка та історичного образу. Переправа на коні через річку Збруч, знята 3 далекої високої точки, уособлює шлях української самоідентифікації, що лежить між двох берегів. А непримітне поле під селом Писарівка Харківської області стає однією з тисяч білих плям національної пам'яті - неозначеним масовим похованням. Безіменні пейзажі також відіграють свою емоційну роль у монтажі - жнива у своєму мовчазному тремтінні; звивиста залізнична колія (одною 3 яких блукав Джонс), що тягнеться по схилах та губиться у деревах; снігова завірюха, котра заморожує землю; жовтогарячий захід сонця, що передвіщає війну.

«Десь знімалося з рук, десь зі штатива. Ми використовували дихаючу камеру для синхронів, для того щоб не “прибивати мертво” в кадрі людину, щоб синхрони все-таки трохи дихали. Камера весь час рухалася, вона дихала кожним рухом. Не можна було ввімкнути камеру і читати журнал, як це роблять оператори (провідні, дуже відомі) на ток-шоу, треба було весь час бути присутнім там. Крихітні кімнатки, маленькі інтер'єри, звичайно ж, природне світло - ніяких бі-бі-сішних заливок. Тільки жива камера.» [17].

Портрети «живих» є виразними через переважно натуральне м'яке бічне світло, увагу до автентичного сільського тла. Ідентифікація з героями підсилюється з жорсткістю зйомки та порушенням шаблонів інтерв'ю: герої входять у кадр, виходять 3 кадру, перебирають під час розмови квасолю.

Іноді кадр $з$ прямою мовою побудований на деталі рук. А іноді руки «говорять» самодостатніше, ніж пряма мова,- коли вони, тремтячи, 
дбайливо викладають на стіл яйця, кілька м'ятних цукерок та буханець хліба.

«Вони вдивлялися в прикмети часу, згадували себе тодішніх і шукали відповіді: чи ми змінили світ, чи світ змінив нас?»

«Украӥна. Точка відліку» (2011) також побудована на людях, що опинились віч-на-віч з екраном. Цього разу на хроніці, що пропонується героям, вони, як і глядачі «Точки відліку» старших поколінь, побачать самих себе. Екран має стати для них сфокусованим рефлектором, випробуванням на споглядання самих себе збоку.

«Чим далі ми від цих подій, тим більше вони зростають». У цих словах історика Ярослава Грицака криється ще одна властивість кінематографічного документа: масштаб часу. На відстані десятиліть події обростають наслідками, вшиваються у тканину історії. Буденний хронікальний репортаж для нащадків може перетворитись у найцінніший літопис.

У «Точці відліку» Сергій Буковський повертається до початку власної кар'єри, до відлуння Чорнобиля. Він згадає помпезний парад на першотравень 1986-го, саме те свято, яке відіб'ється луною у його фільмі. Згадає, яка чудова була картинка по телебаченню, коли на шостий день після вибуху на Хрещатик вивели піонерів. Далеко не в останню чергу точкою відліку для Незалежності стає боротьба за свободу слова та кадру.

Викривальна сила документального кіно завжди містить виклик та має супротив там, де до облич прикипіли маски. Органічними методами, навіть без маніпуляцій і провокацій, воно може одним напівтонним барвником, одним вдалим спостереженням чи підхопленням необережно пущеної прямої мови, забарвити у несподіваний колір так старанно виплекану білу фарбу публічного іміджу.

«У фільмі буде багато музики та пісень, але навряд чи він буде схожий на класичний фільм-концерт. У нас інакше завдання. Мені хочеться розгледіти головного виконавця, осягнути секрети ремесла, наблизити його обличчя максимально близько,розповідає режисер «Океан Ельзи. Бекстейдж» (2014) Сергій Буковський. - Говорячи про події, що відбуваються в нашій країні,- вони знайдуть своє відображення у фільмі. Так чи інакше, наш фільм - це портрет покоління і часу, в якому нам судилося жити. А часи, як відомо, не вибирають. Як це буде зроблено, глядачі побачать у кінотеатрах. Сподіваюся, ми їх не розчаруємо.» [15].

Глядачі цей фільм у кінотеатрах так і не побачили - він, приурочений до 20-річного туру цьо- го гурту, був заблокований цензом його головного персонажа. Марно, що картина була знята титулованим українським оператором нового покоління Сергієм Михальчуком. Камера може роздягнути, і далеко не всім це до вподоби. Портрет покоління та часу залишився за маскою телеекрана.

Але Буковський не зупиняється у дослідженні феномена екранних метаморфоз публічної особистості, й наступний фільм знімає про акторку, яка втілювалась у десятки другорядних ролей,про свою матір. Особистісна лінія власної сім’і, ностальгія за втраченим минулим, непроста роль жінки та жінки у кіно - всі ці теми режисер уже окреслив в «Знаку тире» і наступних роботах і продовжує розвивати у «Головній ролі» (2016). Ця картина певним чином перевертає авторський шаблон, опускається від історизму до мелодраматизму, та водночас і великою мірою поглиблює, підсумовує фільмографію Буковського, повертає його на самий початок - через думки про кінець. Не дивно, що правила гри, котрі режисер встановлює глядачеві на вступі фільму, переосмислюють базові поняття кінематографії.

«Ми балансуємо між грою та правдою. Я вважаю, що в документальному кіно ми нічого не відображаємо, ми не дзеркала, я не дзеркало. Це все одно абсолютно нова історія, новий світ, який створюєш. Документальним способом чи ігровим для мене ця межа дуже тонка, розмита.» [8].

Сьогоднійшній інформаційний простір також розмиває межі між правдою та спекуляцією, художністю та фарсом. У свою чергу дуалізм кіно, яке ніколи не стане повною мірою ані протокольно документальним, ані абсолютно абстрагованим від реальності, існував з самого його початку - фактично, з братів Люм'єр, які навчились непомітно маніпулювати дійсністю (наприклад, запросивши своїх друзів взяти участь у знаменитому прибутті потяга). Дискурс щодо форми та мети кіно і є предметом рефлексії визнаного кінорежисера.

«Ha Docudays UA 2017 можно було побачити межу між фільмами високої зображальної культури та фільмами а-ля випускників Разбежкіної, коли взяв мобільний телефон та пішов знімати. Таке домашнє відео, котре стає знаком естетики. Чи від бідності? Можливо. Хороша техніка та оптика - задоволення не дешеве. А знімати ж хочеться. Тому схопили маленькі камери та побігли знімати.

Але я люблю, коли кадри осмислені, як у картині Аудрюса Стоніса “Жінка і льодовик”. Я завжди відрізню прибалтійську школу від будь-яких 
інших. Зображальна культура у ній дуже висока. Не уявляю, як мобільним телефоном можна було б зняти такий фільм.» [16].

Твір мистецтва за Буковським складається не лише 3 доступності інструментарію, а передусім $€$ результатом емпіричної та інтелектуальної роботи, авторської думки, зображальної естетики. Кожен має олівець та папір, та не кожен може стати письменником. Окрім того, кіно для Буковського є наслідком співтворчості, симбіозом творчих інтенцій багатьох людей, а не лише одного амбіційного автора. У «Головній ролі» режисер ділився 3 оператором спостереженнями за станом світла у різні часи доби у квартирі героїні, а оператор, як і в попередніх картинах, ставав його «очима i вухами». Важливо, що такий авторський симбіоз не стає формальним, не спрямований лише на фаховий успіх та визнання, не спирається лише на стильову тенденційність та фестивальні запити на актуальну тематику. Сергій Буковський $з$ сумом констатує, що сучасні автори схильні або до мімікрії до побаченого у кінопросторі, або до створення гламурного, відірваного від реальності світу: «...3 кіно йдуть сенси, це правда». [18, 1:15:55].

Документаліста, незважаючи на його лише 57-річний вік, деякі продюсери називають, за його ж словами, представником «старої школи» [3], визнаючи таким чином численні регалії, але i зауважуючи консервативність стилю. Та «старість» його школи полягає у глибині підходу, у такті та досвіді, врешті-решт у виваженості кінематографічних ритмів - але аж ніяк не у закостенілості та відчуженості. Бачення Буковського можна назвати скоріше позачасним, ніж застарілим - у своєму живому, безпосередньому погляді на людину автор завжди залишатиметься молодим і актуальним.

«Вищий операторський пілотаж - коли його не видно, коли він непомітний, так само, як і режисерський. Якщо тебе видно “о, як я склеїв, о, як я дав!” — це все неправильно. Фільм — це окрема істота, вищий пілотаж режисури - це кіно, коли начебто ти там нічого не робив, начебто воно там само все склалося, коли ти не бачиш ні швів, ні стиків.» [17].

Врешті, людина навпроти екрана у фільмах Сергія Буковського - не лише його герої, а й він сам. Він — як щирий прихильник кіно, він — як нащадок своєї епохи. Екран для нього стає носієм часу, формотворцем пам'яті та історії, головним героєм. Можливо, тільки до всеосяжного екрана режисер і може звернутись словами “хто ми $\epsilon$ ?». I отримати відповідь.

\section{Джерела та література}

1. A talk with Chris Doyle // Camerimage Film Festival, 2017. URL: http://www. facebook. com/camerimage.

2. Буковський С. А. В поисках названия (сезон 2, вып. 26). Владимир Кукоренчук / Сергій Анатолійович Буковський // Old Fashioned Radio. 2016. URL: https://www. mixcloud. com/OFRUkraine/в-поисках-названия-сезон-2-выпуск-26-владимир-кукоренчук/.

3. Стюарт М., Бассель Д.Сергій Буковський: Мені лише 54, а я вже представник «старої школи» // Docudays UA. 2015. URL: http://docudays. org. ua/2015/news/intervyu/ interview_bukovsky/.

4. Зінченко Л. Сергій Буковський та новий кінематографічний погляд на історію // «Українське кіно від 1960-х до съогодні. Проблема виживання» Збірник наукових статей; упоряд. Л.Брюховецька. Київ: вид-во «Задруга», 2010. C. $165-175$.

5. Зубавіна І.Б. Кінематограф незалежної України: тенденції, фільми, постаті / Інститут проблем сучасного мистецтва Академії мистецтв України. Київ: ФЕНІКС, 2007. C. 296.

6. Міщенко М.М. Документальний кінематограф України: між історичною реконструкцією та філософським осмисленням // Вісник Харківського національного університету ім. В. Н. Каразіна. Серія: Філософія. Філософські перипетіï. 2014. № 1116. Вип. 50. С. 47-51. URL: http://nbuv. gov. ua/UJRN/VKhIFLO_2014_1116_50_9

7. Константинова К. Сергій Буковський: усе про мою матір // Дзеркало тижня. 2017. № 1134. URL: http://dt. ua/ CULTURE/sergiy-bukovskiy-use-pro-moyu-matir-_. html

8. Куровець О.Сергій Буковський: «Думка - це подруга, яка нині рідко відвідує голови» // Moviegram. 2017. URL: http://moviegram. com. ua/serhij-bukovskyj-interview/.

9. Буковський Сергій Анатолійович // 1576. иа-Бібліотека Українського світу. URL: http://1576. ua/people/6933.

10. Буковський Сергій Анатолійович // From Wikipedia, the free encyclopedia.—URL: http://uk. wikipedia. org/wiki/Бyковський_Сергій_Анатолійович

11. Майстер-клас Сергія Буковского // Одеський міжнародний кінофестиваль. 2015. URL: https://www. youtube. $\mathrm{com} / \mathrm{watch}$ ? $\mathrm{v}=$ Yc7DF5NUOw0\&t $=$.

12. Чорнобиль - Хроніка важких тижнів // From Wikipedia, the free encyclopedia. URL: https://uk. wikipedia. org/wiki/ Чорнобиль__ХХроніка_важких_тижнів.

13. Жан Бодрійяр. Симулякри і симуляція / пер. $з$ франц. Володимира Ховхуна. Київ. Вид-во Соломії Павличко «Основи», 2004. $231 \mathrm{c.}$

14. Десятерик Д. Сергій Буковський: Люди поступово зрозуміють, що сталося. Головне - строєм нікого нікуди не заганяти // газ. «День». 2009. № 67. URL: http://day. kyiv. ua/uk/article/intervyu/sergiy-bukovskiy-lyudi-postupovozrozumiyut-shcho-stalosya-golovne-stroiem-nikogo

15. Закінчилися зйомки фільму про культову українську рок-групу Океан Ельзи під робочою назвою «OE. Backstage»// сайm компанії Film. иа. 2014. URL: https://film. ua/uk/news/1123.

16. Пензий А.Сергей Буковский: «Превратишься ли ты в циника, как герой Кесьлёвского,- это уже дело твоей совести, снов и покоя» // LB. ua. 2017. URL: http://lb. ua/culture/2017/04/14/363945_sergey_bukovskiy_ prevratishsya_li. html

17. Лігачова Н. Сергій Буковський: «Усі мої фільми об'єднує питання “хто ми $є$ ?”》 // «Детектор медіа». 2008. № 12. URL: http://detector. media/community/article/42973/200812-31-sergei-bukovskii-vse-moi-filmy-obedinyaet-voproskto-my-est

18. DOCU/KЛАC: Розмова Сергія Буковського та Павла Лозінського / Публічна розмова двох відомих режисе- 
рів, чиї останні фільми ввійшли в позаконкурсну програму «Майстри» фестивалю Docudays UA 2017 року. // Docudays UA IHRDFF. 2018. URL: https://www. youtube. $\mathrm{com} /$ watch? $=$ Mfvv7MgDy_Y\&t

\section{References}

1. A talk with Chris Doyle (2017) // Camerimage Film Festival. URL: http://www. facebook. com/camerimage

2. Bukovskyi, S.A.In search of the name (sezon 2, vyp. 26) (2016) - Vladymyr Kukorenchuk / Serhiy Anatoliyovych Bukovskyi // Old Fashioned Radio. URL: //www. mixcloud. com/OFRUkraine/в-поисках-названия-сезон-2-выпуск-26-владимир-кукоренчук

3. Styuart, M., Bassel' D. (2915). Serhii Bukovskyi: Meni lyshe 54 , a ya vzhe predstavnyk "staroyi shkoly» // Docudays UA. 2015. URL: //docudays. org. ua/2015/news/intervyu/ interview_bukovsky

4. Zinchenko, L. (2010) Serhii Bukovskyi and new cinematographic look to history // «Ukrayins'ke kino vid 1960-kh do s'ohodni. Problema vyzhyvannya» Zbirnyk naukovykh statey / Uporyad. L. Bryukhovets'ka. Kyiv: vydvo «Zadruha». S. 165-175 [in Ukrainian].

5. Zubavina, I. B. (2007). Cinema of independent Ukraine: tendencies, films, figures / Instytut problem suchasnoho mystetstva Akademiyi mystetstv Ukrayiny. Kyiv: FENIKS. S. 296 [in Ukrainian].

6. Mishchenko, M. M. (2014). Documentary cinema of Ukraine: between a historicalreconstruction and philosophical comprehension // Visnyk Kharkivskoho natsionalnoho universytetu im. V. N. Karazina. Seriya: Filosofiya. Filosofs'ki perypetiyi. № 1116. Vyp. 50. S. 47-51 [in Ukrainian]. URL: http://nbuv. gov. ua/UJRN/VKhIFLO_2014_1116_50_9

7. Konstantynova, K. (2017). Serhii Bukovskyi: all about my mother // Dzerkalo tyzhnya. № 1134. URL: http://dt. ua/ CULTURE/sergiy-bukovskiy-use-pro-moyu-matir- . html

8. Kurovets, O. (2017). Serhii Bukovskyi: «An idea is a friend that presently rarelyvisits heads» // Moviegram. URL: http://moviegram. com. ua/serhij-bukovskyjinterview.
9. Bukovskyi, Serhii Anatoliyovych // 1576. ua-Biblioteka Ukrayins 'koho svitu. URL: http://1576. ua/people/6933

10. Bukovskyi, Serhii Anatoliyovych // From Wikipedia, the free encyclopedia. URL: http://uk. wikipedia. org/wiki/Буковський_Сергій_Анатолійович

11. Mayster-klas Serhiya Bukovskoho (2015) // Odeskyy mizhnarodnyy kinofestyval'. URL: ttps://www. youtube. com/ watch? $v=$ Yc7DF5NUOw0\&t=

12. Chornobyl - Khronika vazhkykh tyzhniv // From Wikipedia, the free encyclopedia. URL: https://uk. wikipedia. org/wiki/ Чорнобиль_-_Хроніка_важких_тижнів.

13. Bodriyar, Zhan (2004). «Simulacra and simulation»/ per. z frants. Volodymyra Khovkhuna. Kyiv. Vyd-vo Solomii Pavlychko «Osnovy». 231 [in Ukrainian].

14. Desyateryk, D. (2009). Serhii Bukovskyi: People will understand gradually, that happened. Holovne - stroyem nikoho nikudy ne zahanyaty // hazeta «Den'». № 67. URL: http://day. kyiv. ua/uk/article/intervyu/sergiy-bukovskiylyudi-postupovo-zrozumiyut-shcho-stalosya-golovnestroiem-nikogo

15. Zakinchylysya zyomky fil'mu pro kul'tovu ukrayins'ku rokhrupu Okean El'zy pid robochoyu nazvoyu «OE. Backstage» (2014) // sayt kompaniyi Film. ua. URL: //film. ua/uk/ news/1123.

16. Penzii, A. (2017). Serhey Bukovskyy: «Prevratysh'sya ly ty $\mathrm{v}$ tsynyka, kak heroy Keslëvskoho,- éto uzhe delo tvoey sovesty, snov y pokoya» // $L B$. ua. URL: http://lb. ua/culture/2017/04/14/363945_sergey_bukovskiy_ prevratishsya_li. html

17. Lihacheva, $\bar{N}$. (2008). Serhii Bukovskyi: «Usi moyi filmy obyenuye pytannya "khto my ye?"» // "Detektor media». № 12. URL: http://detector. media/community/ article/42973/2008-12-31-sergei-bukovskii-vse-moi-filmyobedinyaet-vopros-kto-my-est

18. DOCU/KLAS: Rozmova Serhiya Bukovskoho ta Pavla Lozins'koho / Publichna rozmova dvokh vidomykh rezhyseriv, chyyi ostanni fil'my vviyshly v pozakonkursnu prohramu «Maystry» festyvalyu Docudays UA 2017 roku (2018). // Docudays UA IHRDFF. URL: https://www. youtube. com/watch?v=Mfvv7MgDy_Y\&t 